HortSCIENCE 27(7):824-826. 1992.

\title{
Developmental Stage, Light, and Foliage Removal Affect Flowering and Bulb Weight of Easter Lily
}

\author{
Yin-Tung Wang and Lori L. Gregg ${ }^{2}$ \\ Texas A\&M University Agricultural Research and Extension Center, \\ 2415 East Highway 83, Weslaco, TX 78596 \\ Additional index words. Lilium longiflorum, carbohydrate supply
}

\begin{abstract}
Lilium longiflorum Thunb. 'Nellie White' plants grown under 1300 $\mu \mathrm{mol} \cdot \mathrm{m}^{-2} \cdot \mathrm{s}^{-1}$ maximum photosynthetic photon flux (PPF) in a greenhouse deliberately were completely defoliated when the oldest flower bud was 2,4 , or $7 \mathrm{~cm}$ long. Plants were then placed in growth chambers in darkness or in the light $\left(250 \mu \mathrm{mol} \cdot \mathrm{m}^{-2} \cdot \mathrm{s}^{-1}\right.$ PPF, 10 hours) with $25 \mathrm{C}$ air, along with intact plants as controls; all were harvested at the completion of flowering. Defoliation at the 2- and 4-cm bud stages resulted in complete flower abortion, with or without light. Plants defoliated at the $7-\mathrm{cm}$ stage and kept in light had $60 \%$ of the flower buds develop to anthesis but depleted more scale reserves. Those defoliated at the $7-\mathrm{cm}$ stage and kept in darkness had complete flower abortion; however, bulb weights remained similar to those of the intact plants kept in the light.
\end{abstract}

Easter lily bulbs store a large quantity of carbohydrate reserves in their scales for later use (Blaney and Roberts; 1966; Wang and Breen, 1987). Under high light conditions, reserves in the mother scales at bulb harvest are depleted rapidly during the establishment of the new flowering shoot, whereas reserves in the daughter scales are rarely used (Roberts et al., 1983; Wang and Breen, 1987). In a recent study, Miller and Langhans (1989) found that reserves in daughter scales were partially depleted in plants grown from flower initiation to anthesis under reduced irradiance. Heins et al. (1982a), however, reported that the rate of Easter lily plant development from visible bud to anthesis was

Received for publication 16 Aug. 1991. Accepted for publication 4 Mar. 1992. Easter lily bulbs were donated by the Pacific Bulb Growers Association Research and Development Center, Harbor, Ore. PBA was supplied by Abbott Lab., North Chicago, Ill. The cost of publishing this paper was defrayed in part by the payment of page charges. Under postal regulations, this paper therefore must be hereby marked advertisement solely to indicate this fact.

'Associate Professor.

${ }^{2}$ Technician II. influenced by temperature but not light intensity.

A 5-day short-term light stress imposed during the early stages of lily plant development did not adversely affect flower count (Heins et al., 1982b). While a 50\% reduction in natural light level either from emergence or from visible bud stage to flowering did not affect the number of flowers reaching anthesis (Heins et al., 1982a; Miller and Langhans, 1989), 85\% light exclusion resulted in many aborted buds (Miller and Langhans, 1989). Heins et al. (1982a) reported that East lily bulbs forced in complete darkness reached anthesis; however, no data on the dry weight of various plant parts or flower quality were presented. How prolonged light stress imposed at various stages following the visible bud stage would affect growth and flowering of Easter lily produced under high light before the light stress period is not known. Also of interest would be whether there is a critical stage after which flower buds can draw scale reserves when $\mathrm{C}$ supply from the foliage is severely decreased as a result of suddenly reduced leaf area or light level.

The objectives of this study were to determine the development of Easter lily flower 
Table 1. Effect of light and complete defoliation at various bud developmental stages on Easter lily flowering in growth chambers held at $25 \mathrm{C}$.

\begin{tabular}{|c|c|c|c|c|c|c|}
\hline \multirow{3}{*}{$\begin{array}{c}\text { Flower } \\
\text { bud length } \\
\text { (cm) }\end{array}$} & \multicolumn{4}{|c|}{ Dry wt (g) } & \multirow{3}{*}{$\begin{array}{l}\text { Mean } \\
\text { flower } \\
\text { length } \\
(\mathrm{cm})\end{array}$} & \multirow{3}{*}{$\begin{array}{c}\text { Aborted bud } \\
(\%)\end{array}$} \\
\hline & \multicolumn{3}{|c|}{ Flower no. } & \multirow[b]{2}{*}{ Total } & & \\
\hline & 1 & 2 & 3 & & & \\
\hline \multicolumn{7}{|c|}{ In light $\left(250 \mu\right.$ molm $\left.{ }^{-2} \cdot \mathrm{s}^{-1}\right)$} \\
\hline $\begin{array}{l}2 \\
4 \\
7 \\
\text { Control }\end{array}$ & $\begin{array}{l}0.05 c^{y} \\
0.24 c \\
1.16 \mathrm{~b} \\
1.61 \mathrm{a}\end{array}$ & $\begin{array}{l}0.04 \mathrm{c} \\
0.19 \mathrm{c} \\
1.11 \mathrm{~b} \\
1.63 \mathrm{a}\end{array}$ & $\begin{array}{l}0.03 \mathrm{c} \\
0.12 \mathrm{c} \\
0.82 \mathrm{~b} \\
1.50 \mathrm{a}\end{array}$ & $\begin{array}{l}0.13 \mathrm{c} \\
0.55 \mathrm{c} \\
3.09 \mathrm{~b} \\
4.75 \mathrm{a}\end{array}$ & $\begin{array}{c}\ldots . . x \\
18.4 \text { a } \\
18.8 \text { a }\end{array}$ & $\begin{array}{r}100 \mathrm{a} \\
100 \mathrm{a} \\
40 \mathrm{~b} \\
4 \mathrm{c}\end{array}$ \\
\hline \multicolumn{7}{|c|}{ In darkness } \\
\hline $\begin{array}{l}2 \\
4 \\
7 \\
\text { Control } \\
\text { Light vs. dark }\end{array}$ & $\begin{array}{l}0.05 \mathrm{c} \\
0.26 \mathrm{a} \\
0.21 \mathrm{~b} \\
0.21 \mathrm{~b}\end{array}$ & $\begin{array}{l}0.04 \mathrm{~b} \\
0.20 \mathrm{a} \\
0.17 \mathrm{a} \\
0.14 \mathrm{a}\end{array}$ & $\begin{array}{l}0.03 \mathrm{~b} \\
0.12 \mathrm{a} \\
0.10 \mathrm{a} \\
0.08 \mathrm{a} \\
* *\end{array}$ & $\begin{array}{l}0.12 \mathrm{~b} \\
0.58 \mathrm{a} \\
0.48 \mathrm{a} \\
0.44 \mathrm{a}\end{array}$ & $\begin{array}{l}\ldots x \\
\cdots \\
\cdots \\
\cdots\end{array}$ & $\begin{array}{c}100 \mathrm{a} \\
100 \mathrm{a} \\
100 \mathrm{a} \\
100 \mathrm{a} \\
* *\end{array}$ \\
\hline
\end{tabular}

${ }^{2}$ When leaves were removed.

yean separation in each column within each light level by Duncan's multiple range test at $\alpha=0.05$.

${ }^{x}$ Flower buds aborted.

** Significant at $\alpha=0.01$.

Table 2. Effect of light and complete defoliation at three developmental stages on the growth of Easter lily stem and storage organs.

\begin{tabular}{|c|c|c|c|c|c|}
\hline \multirow{3}{*}{$\begin{array}{l}\text { Flower } \\
\text { bud lengthz } \\
(\mathrm{cm})\end{array}$} & \multirow{3}{*}{$\begin{array}{c}\text { Stem } \\
\text { dry wt } \\
\text { (g) }\end{array}$} & \multicolumn{3}{|c|}{ Dry wt (g) } & \multirow{3}{*}{$\begin{array}{l}\text { Dry wt } \\
\text { in mother } \\
\text { scales (\%) }\end{array}$} \\
\hline & & \multicolumn{2}{|c|}{ Scale type } & \multirow[b]{2}{*}{ Total } & \\
\hline & & Mother & Daughter & & \\
\hline \multicolumn{6}{|c|}{ In light $\left(250 \mu \mathrm{mol} \mathrm{m}^{-2} \cdot \mathrm{s}^{-1}\right)$} \\
\hline $\begin{array}{l}2 \\
4 \\
7 \\
\text { Control }\end{array}$ & $\begin{array}{l}2.7 \mathrm{cy}^{y} \\
3.0 \mathrm{c} \\
5.3 \mathrm{~b} \\
7.8 \mathrm{a}\end{array}$ & $\begin{array}{l}17.0 \mathrm{a} \\
16.2 \mathrm{ab} \\
13.4 \mathrm{~b} \\
18.9 \mathrm{a}\end{array}$ & $\begin{array}{l}3.5 \mathrm{a} \\
2.8 \mathrm{a} \\
2.6 \mathrm{a} \\
3.6 \mathrm{a}\end{array}$ & $\begin{array}{l}20.5 \mathrm{a} \\
19.0 \mathrm{ab} \\
16.0 \mathrm{~b} \\
22.5 \mathrm{a}\end{array}$ & $\begin{array}{l}26.0 \mathrm{bc} \\
26.6 \mathrm{ab} \\
24.1 \mathrm{c} \\
28.8 \mathrm{a}\end{array}$ \\
\hline \multicolumn{6}{|c|}{ In darkness } \\
\hline $\begin{array}{l}2 \\
4 \\
7 \\
\text { Control } \\
\text { Light vs. dark } \\
\end{array}$ & $\begin{array}{l}3.3 \mathrm{~b} \\
3.3 \mathrm{~b} \\
4.0 \mathrm{ab} \\
4.5 \mathrm{a} \\
* *\end{array}$ & $\begin{array}{c}17.1 \mathrm{a} \\
13.6 \mathrm{~b} \\
15.3 \mathrm{ab} \\
17.3 \mathrm{a} \\
\text { NS }\end{array}$ & $\begin{array}{c}3.2 \mathrm{a} \\
3.5 \mathrm{a} \\
2.5 \mathrm{a} \\
3.2 \mathrm{a} \\
\mathrm{NS}\end{array}$ & $\begin{array}{c}20.3 \mathrm{a} \\
17.1 \mathrm{a} \\
18.8 \mathrm{a} \\
20.5 \mathrm{a} \\
\text { NS }\end{array}$ & $\begin{array}{l}26.2 \mathrm{~b} \\
26.5 \mathrm{~b} \\
29.2 \mathrm{a} \\
29.0 \mathrm{a}\end{array}$ \\
\hline
\end{tabular}

${ }^{2}$ When leaves were removed.

'Mean separation in each column within each light level by Duncan's multiple range test at $\alpha=0.05$. Ns,** Nonsignificant and significant at $\alpha=0.01$, respectively.

buds and the status of the bulb when the supply of current photoassimilate was drastically reduced at various flower developmental stages.

'Nellie White' Easter lily bulbs (20 to 22.5 $\mathrm{cm}$ in circumference) were stored for 6 weeks at $4.5 \mathrm{C}$ in moist peatmoss and then planted one per 2.6-liter pot on 28 Nov. 1990 using a peat-lite medium. Pots were placed in a greenhouse with a $1300 \mu \mathrm{mol} \cdot \mathrm{m}^{-2} \cdot \mathrm{s}^{-1}$ maximum photosynthetic photon flux (PPF) measured at solar noon with a LI-185B meter and a LI-190SB quantum sensor (LI-COR, Lincoln, Neb.). Plants were fertilized with water containing $1.5 \mathrm{~g} 20 \mathrm{~N}-8.6 \mathrm{P}-16.6 \mathrm{~K} / \mathrm{li}-$ ter soluble fertilizer with trace elements. The medium was occasionally flushed with water containing no fertilizer to prevent the accumulation of salts. Shoots emerged by late December. Air in the greenhouse was maintained between 28C (day maximum) and 12C (night minimum).

On 26 Feb. 1991, two groups of 20 plants each, with the oldest flower bud 2 or $4 \mathrm{~cm}$ long, were selected. Leaves and bracts were removed from all plants, leaving only the flower buds on each stem. Five plants from each group were placed in a growth chamber (Model GC-15; Environmental Growth Chambers, Chagrin Falls, Ohio) with $10 \mathrm{~h}$ of $250 \mu \mathrm{mol} \cdot \mathrm{m}^{-2} \cdot \mathrm{s}^{-1} \mathrm{PPF}$ (fluorescent and incandescent light) at the bud level, $25 \pm$ $1 \mathrm{C}$ air, and $85 \%$ relative humidity. The other plants were moved into another chamber under similar conditions, except there was no light.

Ten additional intact plants were also moved into each growth chamber. On 5 Mar., when the oldest flower bud on intact plants in the lighted chamber was $7 \mathrm{~cm}$ long $(5 \mathrm{~cm}$ on those intact plants in darkness), all leaves and bracts were removed from five plants in each chamber. Five intact plants in each chamber were used as controls. Each plant represented an experimental unit. All treatments were replicated five times and randomized in a complete block design.

The lengths and dry weights of the three oldest flowers on each plant were recorded individually as they reached anthesis. Percent flower bud abortion (as defined by De Hertogh et al., 1971) was determined for each plant. Bulbs were harvested on 28 Mar. after flowering was completed, and dry weights of daughter and mother scales were determined separately.

All buds aborted when plants were defoliated at the 2- or 4-cm stage, with or without subsequent light. However, when plants were allowed to develop buds to the 7-cm stage, only $40 \%$ of the buds on lighted plants aborted, whereas all buds on plants held in darkness aborted (Table 1). Those flowers reaching anthesis had a lower dry weight than the controls, although flower length was unaffected (Table 1). Dry weights of opened flowers from intact plants in the lighted growth chamber (Table 1) were similar to those published previously (Wang and Breen, 1984). Removing all leaves on Easter lily after 10 to 40 leaves had unfolded resulted in the abortion of most flower initials (Roberts and Blaney, 1968) during forcing at 15.5C. Since the development of flower buds depends heavily on the current photoassimilate (Wang and Breen, 1986, 1987), flower buds at the 2- and 4-cm stages may not have developed adequate sink strength to mobilize the scale reserves (Roberts and Blaney, 1968). Although many flower buds on the plants defoliated at the 7-cm stage reached anthesis, exposure to light is necessary for these flower buds to sustain their growth. The light level and duration used in this study were adequate (Wilkins et al., 1986) for flower bud development of intact plants.

Complete defoliation restricted stem growth by inhibiting stem elongation (data not shown) and dry matter accumulation as compared to intact plants (Table 2). This leaf-mediated stem growth also was reported by Roberts and Blaney (1968), and the removal of terminal leaves had more effect on stem elongation than the removal of basal leaves. However, the young, developing flower buds probably had more effect on stem elongation than leaves because removing the young flower buds without damage to the foliage prevented normal stem elongation and leaf expansion (Wang and Breen, 1986). Mother scales of lighted plants with their leaves removed at the 7-cm bud stage had a lower dry weight and a lower percentage of dry matter when compared to others under similar conditions, likely the result of additional depletion of scale reserves by developing flower buds. Leaf removal and light treatment had no effect on daughter scale weight (Table 2).

Although a large amount of scale reserves was depleted during Easter lily shoot growth, dry matter loss from the scales essentially stopped when flower buds were about $2 \mathrm{~cm}$ long (Wang and Breen, 1987). Studies using ${ }^{14} \mathrm{C}$ as a tracer have determined that the development of flower buds on an intact plant under high PPF relies on the current photoassimilate from the foliage and requires little or no $\mathrm{C}$ directly from the scale reserves (Wang and Breen, 1986, 1987). Miller and Langhans (1989) found that Easter lily grown continuously under progressively reduced light levels used increasing amounts of scale reserves for growth and development. How- 
ever, removing each leaf as it unfolded conserved the reserves in mother scales and caused severely stunted stem elongation and flower bud abortion (Roberts and Blaney, 1968). This current defoliation study provides evidence that, when current photoassimilate supply of an Easter lily produced under high light is severely restricted during flower development by complete leaf removal, flower buds have to reach a certain developmental stage $(\geq 7 \mathrm{~cm})$ before they develop sufficient mobilization force to draw scale reserves. Flower buds at the $7-\mathrm{cm}$ stage had accumulated half of their final dry matter (Wang and Breen, 1984) and this could be a critical stage to determine their survival under severe $\mathrm{C}$ stress. This critical stage may have been associated with a certain cell activity, such as the miotic phase of the megasporocyte (Durieux et al., 1983) or microspore mitosis (Erickson, 1948). Microspore mitosis is accompanied by a drop in respiration rate of the whole anther (Erickson, 1948), which may have accounted for the drop in flower bud respiration rate between 6.5 and $7.5 \mathrm{~cm}$ (Wang and Breen, 1984).

All flower buds on intact and defoliated plants failed to develop further in darkness although $\mathrm{C}$ reserves in their scales were ample. Durieux et al. (1983) reported that flower bud abscission induced by darkness seems to be restricted to a critical stage in the development of the bud in Lilium 'Enchantment'. Our results conflict with those observed by Heins et al. (1982a) that Easter lily can be forced to bloom in complete darkness. It appears that the presence of light is a necessity to assist flower buds in drawing $\mathrm{C}$ from the scales when the supply of current photoassimilate is greatly diminished, as in plants produced under high light and then deprived of light when the oldest flower bud was between 2 and $4 \mathrm{~cm}$ long (Table 1). Easter lily forced in the dark from shoot emergence (Heins et al., 1982a) may perform differently from those moved into darkness after being produced under high light. As long as there was light above a certain level, neither a long-term (Miller and Langhans, 1989) nor a month-long (Table 1) reduction in light level appeared to affect flower length since nearly all bulbs on our control plants reached anthesis with excellent quality. Durieux et al. (1983) also noted that, although there is a large reservoir of metabolites in the bulb of lily and iris (Iris hollandica), flowering of these plants is only certain when plants receive adequate light.

In conclusion, exposure to light and a minimum developmental stage (flower buds $7 \mathrm{~cm}$ long) appear to be required for lily buds to draw scale reserves when current photoassimilate supply is severely limited due to the absence of the fully established foliage.

\section{Literature Cited}

Blaney, L.T. and A.N. Roberts. 1966. Growth and development of the Easter lily bulb, Lilium longiflorum Thunb. 'Croft'. Proc. Amer. Soc. Hort. Sci. 89:643-650.
De Hertogh, A.A., A.N. Roberts, N.W. Stuart, R.W. Langhans, R.G. Lindennan, R.H. Lawson, H.F. Wilkins, and D.C. Kiplinger. 1971. A guide to terminology for the Easter lily ( $\mathrm{Lil}$ ium longiflorum Thunb.) HortScience 6:121123.

Durieux, A.J.B., G.A. Kamerbeek, and U. van Meeteren. 1983. The existence of a critical period for the abscission and a non-critical period for blasting of flower-buds of Lilium 'Enchantment'; influence of light and ethylene. Scientia Hort. 18:287-297.

Erickson, R.O. 1948. cytological and growth correlations in the flower bud and anther of Lilium longiflorum. Amer. J. Bot. 35:729-739.

Heins, R.D., H.B. Pemberton, and H.F. Wilkins. 1982a. The influence of light on lily Lilium longiflorum Thunb.). I. Influence of light intensity on plant development. J. Amer. Soc. Hort. Sci. 107:330-335.

Heins, R.D., H.F. Wilkins, and W.E. Healy. 1982b. The influence of light on lily (Lilium longiflorum Thunb.). II. Influence of photoperiod and light stress on flower number, height, and growth rate. J. Amer. Soc. Hort. Sci. 107:335-338.

Miller, W.B. and R.W. Langhans. 1989. Reduced irradiance affects dry weight partitioning in Easter lily. J. Amer. Soc. Hort. Sci. 114:306-309.

Roberts, A.N. and L.T. Blaney. 1968. Effects of vernalization and partial defoliation on flowering and correlative relationships in Lilium longiflorum, Thunb. 'Croft'. Proc. Amer. Soc. Hort. Sci. 92:647-664.

Roberts, A.N., Y.T. Wang, and F.W. Moeller. 1983. Effect of pre- and post-bloom temperature regimes on development of Lilium longiflorum Thunb. Scientia Hort. 18:363-379.

Wang, Y.T. and P.J. Breen. 1984. Respiration and weight changes of Easter lily flowers during development. HortScience 19:702-703.

Wang, Y.T. and P.J. Breen. 1986. Partitioning of ${ }^{14} \mathrm{C}$-assimilate in Easter lily as affected by growth stage and flower removal. Scientia Hort. 29:273281 .

Wang, Y.T. and P.J. Breen. 1987. Distribution, storage, and remobilization of ${ }^{14} \mathrm{C}$-labeled assimilate in Easter lily. J. Amer. Soc. Hort. Sci. 112:569-573.

Wilkins, H.F., K. Grueber, W. Healy, and H.B. Pemberton. 1986. Minimum fluorescent light requirements and ancymidol interactions on the growth of Easter lily. J. Amer. Soc. Hort. Sci. 111:384-387. 